\title{
ANALISIS PENGARUH INDIKATOR MAKROEKONOMI TERHADAP IMPOR BARANG INTRA-ASEAN
}

\author{
Lasma Melinda Siahaan \\ Ekonomi Pembangunan, Universitas Quality Medan \\ Email: lasma@universitasquality.ac.id
}

\begin{abstract}
This research aims to determine the factors that affect the amount of imported goods intraASEAN. Factors influencing the import of goods in this study are Gross Domestic Product (GDP), Inflation and Exchange Rate in each member country of ASEAN. The method used in this research is panel regression through Panel Least Square (PLS) by using program Eviews 10. The data used is panel data, consisting of ten ASEAN member countries and ten years of research from 2006 to 2015. The results of the analysis data show that GDP and inflation have a positive and significant effect on the imported goods intra-ASEAN, while the exchange rate has a negative and significant effect on the imported goods intraASEAN. Simultaneously, GDP, inflation and exchange rate have a positive and significant effect on imported goods intra-ASEAN.
\end{abstract}

Keywords: Imported Goods Intra-ASEAN, GDP, Inflation and Exchange Rate.

\section{PENDAHULUAN}

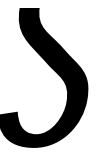

eiring dengan peningkatan jumlah penduduk di suatu negara, kebutuhan akan suatu barang semakin mengalami peningkatan pula. Semakin banyak dan beragamnya kebutuhan masyarakat sering tidak dapat dipenuhi oleh produksi dalam negeri. Sumber daya dalam negeri yang semakin terbatas mengakibatkan kapasitas produksi dalam negeri semakin berkurang untuk menghasilkan barang yang dibutuhkan oleh masyarakat. Hal ini mendorong setiap negara untuk melakukan perdagangan dalam bentuk impor barang dengan negara lain demi memenuhi kebutuhan barang di dalam negeri.

Berbagai kerjasama bilateral dan multilateral dijalin masing-masing negara untuk meningkatkan kesejahteraan masyarakatnya terutama dalam pemenuhan kebutuhan akan barang-barang konsumsi. Hal tersebut berlaku pula bagi negara-negara di kawasan Asia Tenggara yang memutuskan untuk menjalin kerjasama ASEAN. Kerjasama ASEAN,

$$
\text { QE Journal | Vol.07 - N } 0.02 \text { July } 2018-75
$$


terutama dalam bidang ekonomi, ditujukan untuk meningkatkan kesejahteraan masyarakat negara anggotanya. Dalam memenuhi kebutuhan masyarakat akan barang, maka negara anggota ASEAN kerap kali mengutamakan untuk melakukan impor barang antar sesama negara anggota, atau yang lebih dikenal dengan istilah impor intra-ASEAN. Berikut disajikan tabel perkembangan impor barang intra-ASEAN.

Tabel 1. Perkembangan Impor Intra-ASEAN tahun 2006-2015 (juta USD)

\begin{tabular}{ccccccccccc}
\hline Negara & $\mathbf{2 0 0 6}$ & $\mathbf{2 0 0 7}$ & $\mathbf{2 0 0 8}$ & $\mathbf{2 0 0 9}$ & $\mathbf{2 0 1 0}$ & $\mathbf{2 0 1 1}$ & $\mathbf{2 0 1 2}$ & $\mathbf{2 0 1 3}$ & $\mathbf{2 0 1 4}$ & $\mathbf{2 0 1 5}$ \\
\hline Brunei & & & & & & & & & & \\
Darussalam & 743.1 & $1,043.30$ & $1,200.10$ & $1,255.10$ & $1,234.40$ & $1,548.80$ & $1,603.00$ & $1,843.70$ & $1,767.60$ & $1,405.40$ \\
Cambodia & $1,931.80$ & $1,283.00$ & $1,599.30$ & $1,453.30$ & $1,676.00$ & $2,206.60$ & $2,765.40$ & $2,818.20$ & $2,915.80$ & $4,677.30$ \\
Indonesia & $41,686.30$ & $23,792.10$ & $40,991.70$ & $27,742.40$ & $47,124.70$ & $51,300.20$ & $53,823.40$ & $54,031.00$ & $50,903.10$ & $30,032.60$ \\
Lao PDR & 86.8 & 576.5 & $1,490.90$ & $1,480.80$ & $1,487.70$ & $1,857.20$ & $1,684.50$ & $2,617.40$ & $3,486.20$ & $2,778.90$ \\
Malaysia & $96,025.50$ & $37,315.90$ & $34,675.30$ & $31,700.20$ & $44,717.00$ & $52,173.60$ & $54,869.10$ & $55,021.40$ & $53,726.30$ & $46,678.70$ \\
Myanmar & 940.8 & $1,413.10$ & $1,728.20$ & $2,065.90$ & $1,980.90$ & $3,919.20$ & $4,003.50$ & $4,752.70$ & $7,094.10$ & $7,005.30$ \\
Philippines & $41,555.30$ & $12,875.10$ & $14,316.70$ & $11,561.10$ & $16,269.80$ & $15,040.30$ & $14,953.90$ & $14,171.40$ & $16,404.40$ & $17,042.00$ \\
Singapore & $176,181.60$ & $66,629.30$ & $75,141.80$ & $59,158.00$ & $74,924.60$ & $78,501.00$ & $80,234.20$ & $78,181.40$ & $75,770.10$ & $64,874.50$ \\
Thailand & $103,569.00$ & $24,992.50$ & $29,888.20$ & $26,759.50$ & $32,643.00$ & $39,463.10$ & $42,805.00$ & $44,348.10$ & $43,299.50$ & $41,071.80$ \\
Viet Nam & $27,783.10$ & $15,444.50$ & $19,476.80$ & $13,566.70$ & $16,407.50$ & $20,910.20$ & $20,874.60$ & $21,353.00$ & $22,537.10$ & $23,827.40$ \\
\hline
\end{tabular}

Sumber: ASEAN Statistical Year Book 2010 dan 2017 (data diolah)

Dari tabel 1 diatas dapat dijelaskan bahwa terjadi fluktuasi impor barang intra-ASEAN dari tahun 2006 sampai dengan 2015. Adapun negara dengan jumlah impor barang intra-ASEAN terbesar adalah Singapura, disusul Thailand dan Malaysia. Berbagai indikator makroekonomi tentu akan mempengaruhi impor suatu barang. Hal ini sejalan dengan penelitian yang dilakukan oleh Ozturk (2012). Dalam penelitiannya yang berjudul "Macroeconomic Factors Affecting The Import in Turkey", ia mengatakan bahwa kondisi makroekonomi seperti tingkat nilai tukar dan produk domestik bruto membawa dampak signifikan terhadap perubahan jumlah impor di Turki.

Indikator makroekonomi lainnya yang turut berpengaruh terhadap impor barang suatu negara adalah tingkat inflasi. Inflasi menyebabkan harga barang impor menjadi lebih murah daripada barang yang dihasilkan di dalam negeri. Sehingga inflasi ini akan menyebabkan impor barang berkembang lebih cepat (Sukirno, 2008). Dalam penelitian yang dilakukan oleh Mardianto (2014) ditemukan bahwa tingkat inflasi dan PDB secara simultan berpengaruh signifikan terhadap impor barang modal di Indonesia dari tahun 1994-2011. 
Sejalan dengan penelitian sebelumnya, Dewi (2015) dalam penelitiannya yang menganalisis tentang "Pengaruh PDB, Cadangan Devisa dan Kurs Dollar Amerika Serikat terhadap Impor Produk Elektronik di Indonesia tahun 1993-2013" menemukan bahwa PDB dan kurs secara simultan berpengaruh signifikan terhadap impor produk elektronik Indonesia. Secara parsial, PDB memberikan pengaruh positif dan signifikan terhadap impor produk elektronik, sedangkan kurs dolar AS berpengaruh negatif dan signifikan terhadap impor produk elektronik di Indonesia selama periode penelitian.

Berdasarkan kajian empiris sebelumnya, ketiga indikator makroekonomi tersebut memberikan pengaruh signifikan terhadap jumlah impor barang suatu negara. Oleh karena itu, dilakukan penelitian yang berjudul "Analisis Faktor-Faktor yang Mempengaruhi Impor Barang Intra-ASEAN" untuk mengetahui apakah ketiga variabel makroekonomi tersebut memberikan pengaruh signifikan terhadap jumlah impor barang intraASEAN dari tahun 2006-2015.

Menurut Boediono (1993), perdagangan diartikan sebagai proses tukarmenukar yang didasarkan atas kehendak sukarela dari masing-masing pihak. Masing-masing pihak harus mempunyai kebebasan untuk menentukan untung rugi pertukaran tersebut dari sudut pandang kepentingan masing-masing kemudian menentukan apakah bersedia melakukan pertukaran atau tidak. Pada dasarnya pertukaran atau perdagangan timbul karena salah satu atau kedua belah pihak melihat adanya manfaat atau keuntungan tambahan yang bisa diperoleh dari pertukaran tersebut.

Menurut Mohammadi (2011), terdapat hubungan jangka panjang antara pendapatan nasional, inflasi dan nilai tukar terhadap impor riil suatu negara. Pengaruh nilai tukar terhadap impor cenderung akan memberikan dampak negatif, sedangkan pendapatan nasional dan inflasi akan memberikan dampak positif terhadap impor riil suatu negara.

Sejalan dengan penelitian sebelumnya, Isnowati (2015) juga menemukan bahwa adanya hubungan jangka pendek dan jangka panjang antara nilai tukar, pendapatan nasional dan inflasi terhadap harga impor suatu barang di Indonesia. Inflasi, pendapatan nasional dan nilai tukar akan berpengaruh positif terhadap impor. Ketika terjadi depresiasi rupiah maka 
harga impor akan mengalami kenaikan. Demikian halnya dengan inflasi dan pendapatan nasional.

Ulke (2011) menemukan bahwa adanya dinamika dan hubungan jangka panjang antara inflasi dan jumlah impor barang suatu negara. Duasa (2009) mengemukakan bahwa gejolak nilai tukar akan memberikan dampak pada perubahan harga impor sehingga akan mempengaruhi jumlah permintaan akan barang impor yang pada akhirnya akan berdampak pada kondisi ekonomi riil di suatu negara.

Demikian pula menurut Prinadi (2016), bahwa semakin menguatnya nilai tukar rupiah akan membuat volume impor beras Indonesia ikut meningkat. Hal ini karena impor merupakan suatu kegiatan pembelian barang dari negara lain sehingga ada uang yang keluar dari Indonesia ke negara lain. Kegiatan ini memerlukan mata uang asing untuk bertransaksi sehingga uang rupiah harus ditukar terlebih dahulu menjadi uang asing. Pada saat nilai tukar rupiah sedang melemah, maka akan memerlukan lebih banyak rupiah sehingga akan dapat merugikan importir.

\section{METODE PENELITIAN}

\section{Kerangka Konseptual}

Kerangka konseptual digunakan untuk menghubungkan atau menjelaskan secara panjang lebar tentang suatu topik yang akan dibahas. Berdasarkan rumusan masalah yang sudah dijelaskan pada pendahuluan, maka kerangka konseptual yang dapat dibentuk dalam penelitian ini akan menggambarkan hubungan antara produk domestik bruto (PDB), inflasi dan nilai tukar terhadap impor barang intra-ASEAN.

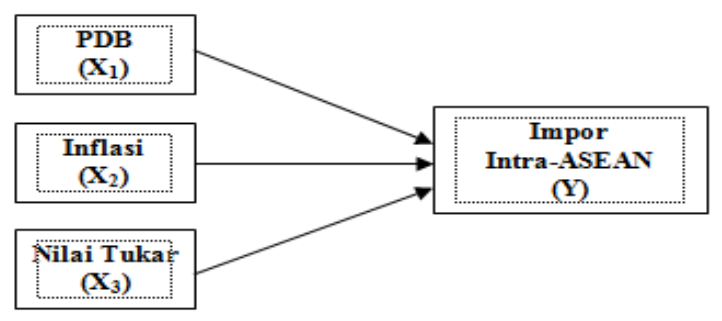

Gambar 1. Kerangka Konseptual

Data yang digunakan adalah data sekunder mengenai PDB, inflasi, nilai tukar dan impor barang intra-ASEAN selama periode tahun 2006-2015. 
Adapun sumber data penelitian adalah diperoleh dari laporan statistik bulanan ASEAN (ASEAN Statistical Yearbook).

\section{Variabel Penelitian}

Yang menjadi variabel bebas adalah variabel PDB $\left(\mathrm{X}_{1}\right)$, inflasi $\left(\mathrm{X}_{2}\right)$ dan nilai tukar $\left(\mathrm{X}_{3}\right)$. Sedangkan yang menjadi variabel terikat adalah variabel impor barang intra-ASEAN (Y).

\section{Teknik Analisis Data}

Analisis regresi yang digunakan adalah regresi panel. Data panel merupakan gabungan antara data cross section dan time series sehingga mampu menyediakan data lebih banyak dan menghasilkan degree of freedom yang lebih besar (Gujarati, 2004). Estimasi dalam model regresi panel dilakukan melalui 3 pendekatan yaitu CEM (Common Effect Model), FEM (Fixed Effect Model), dan REM (Random Effect Model).

\section{CEM (Common Effect Model)}

Model CEM melibatkan seluruh data digabungkan tanpa memperhatikan individu dan waktu. Persamaan model CEM dinyatakan dalam model sebagai berikut:

$$
\mathrm{Y}_{\mathrm{it}}=\alpha+\beta^{\prime} \mathrm{X}_{\mathrm{it}}+\mathrm{e}_{\mathrm{it}}
$$

\section{FEM (Fixed Effect Model)}

Model FEM mengasumsikan bahwa intersep berbeda untuk tiap individu tetapi tetap mengasumsikan bahwa koefisien slope adalah konstan. Persamaan model FEM dinyatakan dalam model sebagai berikut:

$$
Y_{i t}=\alpha+\beta^{\prime} X_{i t}+e_{i t}
$$

Adanya perbedaan intersep dari masing-masing individu ditunjukkan melalui indeks $i$ pada intersep $\left(\alpha_{\mathrm{i}}\right)$.

3.REM (Random Effect Model)

Model REM mengestimasi data panel dimana variabel gangguan mungkin saling berhubungan (error terms) antar waktu dan antar individu. Persamaan REM dapat dinyatakan dalam persamaan sebagai berikut:

$$
Y_{i t}=\alpha+\beta^{\prime} X_{i t}+W_{i t}
$$

Dengan nilai $W_{\text {it }}$

$$
\mathrm{W}_{\mathrm{it}}=\varepsilon_{\mathrm{it}}+\mu_{\mathrm{i}}
$$


Persamaan $w_{\text {it }}$ mengandung komponen error cross section dan time series. Komponen error cross section dilambangkan dengan $\mu_{\mathrm{i}}$, sedangkan komponen error time series dilambangkan dengan $\varepsilon_{i t}$.

Dalam memilih model regresi data panel dilakukan beberapa pengujian antara lain sebagai berikut:

1.Uji Chow

Uji chow untuk memilih model estimasi terbaik antara CEM dan FEM

2.Uji Hausman

Uji hausman digunakan untuk memilih model estimasi terbaik antara FEM dan REM.

3.Uji Lagrange Multiplier

Uji LM digunakan untuk menguji apakah terdapat heterokedastisitas pada model FEM antar kelompok individu cross section.

\section{HASIL DAN PEMBAHASAN}

\section{Pemilihan Model Estimasi}

Pemilihan model estimasi perlu dilakukan dalam analisis regresi data panel. Pemilihan model estimasi ini dilakukan untuk memilih model estimasi terbaik antara Common Effect Model, Fixed Effect Model, atau Random Effect Model yang paling tepat digunakan dalam analisis regresi data panel pada penelitian ini. Metode yang digunakan dalam penelitian ini adalah uji chow dan uji hausman untuk menentukan pemilihan model yang paing tepat dalam mengestimasi data panel.

\section{Uji Chow}

Uji chow digunakan untuk mengetahui model terbaik antara Common Effect Model atau Fixed Effect Model yang akan dipilih untuk estimasi regresi data panel. Hasil uji chow dapat dijelaskan dalam tabel berikut:

Hasil uji chow dibawah menunjukkan bahwa nilai probabilitas Cross section F adalah sebesar 0.0000 dan Cross section Chi-square adalah 0.0000, sehingga nilai probabilitas kurang dari $\alpha$ (Q-value $\square 0.05$ ) yang artinya $\mathrm{H}_{0}$ ditolak. Hasil uji chow ini menunjukkan bahwa model terbaik yang digunakan dalam analisis regresi panel untuk penelitian ini adalah Fixed Effect Model. 
Tabel 2. Hasil Uji Chow

Test cross-section fixed effects

\begin{tabular}{lrrr}
\hline \hline Effects Test & Statistic & d.f. & Prob. \\
\hline \hline Cross-section F & 49.414675 & $(9,87)$ & 0.0000 \\
Cross-section Chi-square & 181.023162 & 9 & 0.0000 \\
\hline \hline
\end{tabular}

\section{Uji Hausman}

Uji hausman digunakan untuk mengetahui model terbaik antara Fixed Effect Model atau Random Effect Model yang akan dipilih untuk estimasi regresi data panel. Hasil uji hasuman dapat dijelaskan dalam tabel berikut:

Tabel 3. Hasil Uji Hausman

Correlated Random Effects - Hausman Test

\begin{tabular}{lccc}
\hline \hline Test Summary & \multicolumn{1}{c}{ Chi-Sq. } \\
Statistic Chi-Sq. d.f. & Prob. \\
\hline \hline Cross-section random & 91.941950 & 3 & 0.0000 \\
\hline \hline
\end{tabular}

Hasil uji hausman menunjukkan bahwa nilai probabilitas Cross section random adalah sebesar 0.0000 , sehingga nilai probabilitas kurang dari $\alpha$ (Qvalue $\square$ 0.05) yang artinya $\mathrm{H}_{0}$ ditolak. Hasil uji hausman ini menunjukkan bahwa model terbaik yang digunakan dalam analisis regresi panel untuk penelitian ini adalah Fixed Effect.

\section{Uji Statistik}

Uji statistik digunakan untuk melihat pengaruh parsial, simultan dan kontribusi dari masing-masing variabel bebas terhadap variabel terikatnya. Hasil uji statistik ditampilkan dalam tabel berikut ini.

\section{Koefisien Determinasi $\left(\mathbf{R}^{2}\right)$}

Koefisien Determinasi atau $\mathrm{R}^{2}$ menunjukkan besarnya kontribusi dari PDB, inflasi dan nilai tukar terhadap impor barang intra-ASEAN. Dari tabel 4 dapat dilihat bahwa nilai R-squared sebesar 0.937710 yang artinya adalah kemampuan variabel PDB, inflasi dan nilai tukar dalam menjelaskan impor barang intra-ASEAN adalah sebesar 93,8\% dan sisanya sebesar 6,2\% dijelaskan oleh variabel lain diluar model estimasi. 
Tabel 4. Hasil Uji Statistik

\begin{tabular}{|c|c|c|c|c|}
\hline \multicolumn{5}{|c|}{$\begin{array}{l}\text { Dependent Variable: Impor_barang } \\
\text { Method: Panel Least Squares } \\
\text { Sample: } 20062015 \\
\text { Total panel (balanced) observations: } 100\end{array}$} \\
\hline Variable & Coefficient & Std. Error & $\mathrm{t}$-Statistic & Prob. \\
\hline PDB & 0.726772 & 0.130571 & 5.566086 & 0.0000 \\
\hline Inflasi & 0.002611 & 0.004458 & 0.585749 & 0.0096 \\
\hline Nilai_tukar & -0.010517 & 0.047343 & -0.222148 & 0.0247 \\
\hline$\overline{\mathrm{C}}$ & 1.050582 & 0.534311 & 1.966237 & 0.0525 \\
\hline \multicolumn{5}{|c|}{ Effects Specification } \\
\hline \multicolumn{5}{|c|}{ Cross-section fixed (dummy variables) } \\
\hline R-squared & 0.937710 & \multicolumn{2}{|c|}{ Mean dependent var } & 4.031609 \\
\hline Adjusted R-squared & 0.929119 & \multicolumn{2}{|c|}{ S.D. dependent var } & 0.699151 \\
\hline S.E. of regression & 0.186139 & \multicolumn{2}{|c|}{ Akaike info criterion } & -0.403909 \\
\hline Sum squared resid & 3.014349 & \multicolumn{2}{|c|}{ Schwarz criterion } & -0.065237 \\
\hline Log likelihood & 33.19547 & \multicolumn{2}{|c|}{ Hannan-Quinn criter. } & -0.266843 \\
\hline F-statistic & 109.1417 & \multirow{2}{*}{\multicolumn{2}{|c|}{ Durbin-Watson stat }} & 0.997864 \\
\hline Prob(F-statistic) & 0.000000 & & & \\
\hline
\end{tabular}

\section{Uji Simultan (Uji-F)}

Uji $F$ digunakan untuk menguji apakah semua variabel bebas yang digunakan memiliki pengaruh simultan terhadap variabel terikat. Hasil dari uji simultan (uji-F) diketahui nilai probabilitas F-statistik adalah sebesar 0.000 dan lebih kecil dari $\alpha=0.05$ sehingga $\mathrm{H}_{0}$ ditolak. Hasil tersebut menunjukkan bahwa variabel PDB, inflasi dan nilai tukar berpengaruh secara simultan terhadap variabel impor barang intraASEAN.

\section{Uji Parsial (Uji-t)}

Uji t digunakan untuk menguji apakah masing-masing variabel bebas memiliki pengaruh secara parsial dan signifikan terhadap variabel terikat. Hasil dari uji t diketahui bahwa nilai koefisien untuk variabel PDB adalah sebesar 0.726772 dengan probabilitas sebesar 0.0000 , yang artinya variabel PDB berpengaruh positif dan signifikan terhadap impor barang intraASEAN.

Untuk variabel inflasi, koefisiennya sebesar 0.002611 dengan nilai probabilitas sebesar 0.0096, yang artinya variabel inflasi berpengaruh positif dan signifikan terhadap impor barang intra-ASEAN. Sedangkan

$$
\text { QE Journal | Vol.07 - N o. } 02 \text { July } 2018 \text { - } 82
$$


koefisien variabel nilai tukar adalah sebesar -0.010517 dengan besarnya nilai probabilitasnya adalah 0.0247 , yang artinya nilai tukar berpengaruh negatif dan signifikan terhadap impor barang intra-ASEAN.

\section{Pengaruh PDB terhadap Impor Barang Intra-ASEAN}

Koefisien variabel PDB yang bertanda positif menunjukkan bahwa setiap kenaikan satu USD PDB negara anggota ASEAN akan meningkatkan impor barang intra-ASEAN sebesar 0.726772 USD. Hasil yang sama juga ditemukan pada penelitian Mardianto (2014) yang menemukan bahwa produk domestik bruto (PDB) berpengaruh positif dan signifikan terhadap volume impor barang modal. Hal ini menunjukkan bahwa semakin besar PDB maka akan semakin tinggi volume impor barang modal di Indonesia.

Sejalan dengan penelitian sebelumnya, Muchlas (2014) dalam penelitiannya juga menemukan hasil positif dan signifikan dalam menggambarkan hubungan antara produk domestik bruto (PDB) Indonesia terhadap impor tekstil dari China. Hal ini diakibatkan semakin meningkatnya jumlah masyarakat "kelas atas" yang menjadikan tekstil berkualitas dan bermerek sebagai kebutuhan. Peningkatan kebutuhan tekstil ini tidak didukung peningkatan produksi tekstil di dalam negeri sehingga harus melakukan impor tekstil dari negara lainnya.

Hasil ini juga didukung oleh penelitian Faisol (2011) yang menyimpulkan bahwa PDB berpengaruh positif dan signifikan terhadap nilai impor di Indonesia. Hasil ini memperkuat teori yang dikemukakan oleh Keynes yang mengemukakan bahwa besar kecilnya impor lebih dipengaruhi oleh pendapatan suatu negara. Analisis makroekonomi menganggap bahwa makin besar pendapatan nasional suatu negara maka akan semakin besar pula nilai impornya.

\section{Pengaruh Inflasi terhadap Impor Barang Intra-ASEAN}

Koefisien variabel inflasi yang bertanda positif menunjukkan bahwa setiap kenaikan satu persen inflasi di negara anggota ASEAN akan meningkatkan impor barang intra-ASEAN sebesar 0.002611 USD. Hasil yang sama juga ditemukan pada penelitian Ramdan (2014) yang menemukan bahwa terdapat pengaruh positif yang signifikan dari tingkat inflasi $(X)$ terhadap volume impor mobil CBU (Y). Tingkat inflasi yang tinggi akan menyebabkan permintaan akan mobil impor CBU mengalami peningkatan. 
Tidak berbeda dengan penelitian sebelumnya, Caraka (2016) dalam penelitiannya yang menganalisis "pengaruh inflasi terhadap impor dan ekspor di Provinsi Riau dan Kepulauan Riau" menemukan bahwa inflasi yang tinggi di dalam negeri akan mengakibatkan harga ekspor barang dan jasa relatif lebih mahal sehingga produksi barang dan jasa dalam negeri tidak akan mampu bersaing dengan barang dan jasa dari luar negeri. Hal ini akan mengakibatkan kenaikan impor barang dan jasa seiring dengan penurunan ekspor barang dan jasa di dalam negeri.

Sejalan dengan penelitian oleh Islam (2013) yang menyimpulkan bahwa terdapat korelasi positif antara inflasi dan impor barang di Bangladesh. Hal ini dipicu dari terjadinya inflasi yang mengakibatkan kenaikan harga di Bangladesh. Kenaikan harga di dalam negeri akan mendorong untuk mengimpor barang dari luar negeri untuk memenuhi kebutuhan masyarakat di dalam negeri karena harga barang di luar negeri dianggap lebih murah sehingga bila inflasi terjadi secara terus-menerus dan relative panjang maka nilai impor barang akan mengalami kenaikan.

\section{Pengaruh Nilai Tukar terhadap Impor Barang Intra-ASEAN}

Koefisien variabel nilai tukar yang bertanda negatif menunjukkan bahwa setiap terjadi penguatan nilai dollar terhadap mata uang negara anggota ASEAN sebesar satu dollar akan menurunkan impor barang intra-ASEAN sebesar -0.010517 USD. Hasil yang sama juga ditemukan pada penelitian Alotaibi (2016) yang mengemukakan bahwa depresiasi mata uang suatu negara akan mendorong penurunan impor barang dari luar negeri. Demikian sebaliknya, penguatan nilai mata uang suatu negara (apresiasi) akan mendorong kenaikan impor barang dari luar negeri.

Nilai tukar terhadap dollar dalam perdagangan internasional dapat menjadi masalah yang serius terutama di negara berkembang. Hal inilah yang dikemukakan oleh Khan (2014) dalam penelitiannya di Pakistan. Ia menyatakan bahwa akan di negara berkembang fluktuasi nilai tukar akan sangat mempengaruhi nilai impor barangnya. Seperti Pakistan yang merupakan negara berkembang, bila nilai tukar terhadap dollar mengalami penguatan maka permintaan akan barang impor akan mengalami penurunan. Hal ini dikarenakan akan semakin banyak mata uang negara tersebut yang akan dikeluarkan untuk membeli barang impor. 
Berbeda dengan penelitian sebelumnya, Oluyemi (2017) dalam penelitiannya yang berjudul "The Effect of Exchange rate on Imports and Exports in Nigeria from January 1996 to June 2015" menemukan bahwa nilai tukar mempunyai dampak positif yang tidak signifikan terhadap impor, sedangkan berdampak negatif terhadap ekspor di Nigeria. Hal ini terjadi karena Nigeria sebagai negara berkembang tidak begitu merasakan keuntungan dari perdagangan internasional yang ada.

\section{SIMPULAN DAN SARAN}

Berdasarkan hasil analisis yang telah dilakukan, maka dapat diambil kesimpulan sebagai berikut:

1. Secara simultan terdapat pengaruh positif dan signifikan antara produk domestik bruto (PDB), inflasi dan nilai tukar terhadap impor barang intra-ASEAN.

2. Secara parsial, produk domestik bruto dan inflasi mempunyai pengaruh positif yang signifikan terhadap impor barang intra-ASEAN. Sedangkan, nilai tukar mempunyai pengaruh negatif yang signifikan terhadap impor barang intra-ASEAN.

Dengan hasil penelitian yang menunjukkan adanya pengaruh positif dan signifikan antara produk domestik bruto, inflasi dan nilai tukar terhadap impor barang intra-ASEAN, maka pemerintah sebaiknya membuat kebijakan makroekonomi yang dapat menstabilkan kondisi perekonomian di masing-masing negara anggota ASEAN seperti kebijakan untuk mengatasi inflasi yang tinggi dan menjaga kestabilan nilai tukar di masingmasing negara serta melakukan pembatasan penggunaan produk domestik bruto (PDB) untuk impor dan mendukung produktivitas produksi dalam negeri.

\section{DAFTAR PUSTAKA}

Alotaibi, Khaled. 2016. How Exchange Rate Influence a Country's Import and Export. International Journal of Scientific E Engineering Research, Volume 7, Issue 5.

Boediono, 1993. Ekonomi Internasional. BPFE: Yogyakarta. 
Caraka, Rezzy Eko, Wawan Sugiyarto, Gustriza Erda dan Erie Sadewo. 2016. pengaruh inflasi terhadap impor dan ekspor di Provinsi Riau dan Kepulauan Riau menggunakan Generalized Spatio Time Series. Jurnal BPPK, Volume 9 Nomor 1.

Dewi, Putu Tjintia Kencana dan I Ketut Sudiana. 2015. Pengaruh PDB, Cadangan Devisa dan Kurs Dollar Amerika Serikat terhadap Impor Produk Elektronik di Indonesia tahun 1993-2013. E-Jurnal Ekonomi Pembangunan Universitas Udayana Vol.4, No. 4.

Duasa, Jarita. 2006. Exchange Rate Shock on Malaysian Prices of Imports and Exports: An Empirical Analysis. Journal of Economic Cooperation and Development, Vol.30, No.3.

Faisol, Nazaruddin Fahmi. 2011. Pengaruh Pertumbuhan Domestik Bruto (PDB), Laju Inflasi dan Nilai Tukar Rupiah terhadap Nilai Impor Indonesia. Prosiding Pluralisme Dalam Ekonomi Dan Pendidikan ISSN 2407-4268.

Gujarati. 2004. Basic Econometrics. New York: Mc Gwra Hill, Inc.

Islam, Md. Ariful. 2013. Impact of Inflation on Import: An Empirical Study. International Journal of Economics, Finance and Management Sciences, Vol.1, No.6.

Isnowati, Sri. 2015. Effect of Exchange Rate, National Income, and Inflation on Import Price in Indonesia. International Journal of Business, Economics and Law, Vol. 7, Issue 3.

Khan, Abdul Jalil, Parvez Azim dan Shabib Haider Syed. 2014. The Impact of Exchange Rate Volatility on Trade: A Panel Study on Pakistan's Trading Partners. The Lahore Journal of Economics, Volume 19 Nomor 1 .

Mardianto, Agung dan I Wayan Wita Kusumajaya. 2014. Pengaruh Inflasi, Cadangan Devisa dan Produk Domestik Bruto terhadap Impor Barang Modal di Indonesia. E-Jurnal Ekonomi Pembangunan Universitas Udayana Vol.3, No. 9.

Mohammadi, T., M. Taghavi dan A. Bandidarian. 2011. The Effect of Exchange Rate Uncertainty on Import: TARCH Approach. International. Journal Management Business Res., Vol. 1 No, 4. 
Muchlas, Zainul dan Agus Rahman Alamsyah. 2014. Pengaruh Harga, Nilai Tukar dan Produk Domestik Bruto Indonesia Terhadap Volume Impor Tekstil dari China. Jurnal JIBEKA Volume 8 No. 2.

Oluyemi, Oloyede. 2017. The Effect of Exchange Rate on Imports and Exports in Nigeria from January 1996 to June 2015. IIARD International Journal of Economics and Business Management, Vol. 3 No. 2.

Ozturk, Mustafa. 2012. Macroeconomic Factors Affecting The Import in Turkey. Journal of Qafqaz University, Number 34, 2012.

Prinadi, Riska, Edy Yulianto dan M. Kholid Mawardi. 2016. Pengaruh Nilai Tukar Rupiah, Harga Beras Internasional dan Produksi Beras Dalam Negeri Terhadap Volume Impor Beras Indonesia ( Studi Impor Beras Indonesia Tahun 2002-2013). Jurnal Administrasi Bisnis (JAB), Vol. 34 No. 1.

Ramdan, Muhamad Rizky, M. Al Musadieq dan Edy Yulianto. 2014. Pengaruh Tingkat Inflasi terhadap Volume Impor Mobil CBU (Completely built Up) dengan Nilai Tukar Rupiah sebagai Variabel Moderasi (Studi pada Volume Impor Mobil CBU Gaikindo Periode tahun 2005-2013). Jurnal Administrasi Bisnis (JAB), Vol. 15 No. 2.

Sukirno, Sadono. 2008. Makro Ekonomi Teori Pengantar. PT. Raja Grafindo Persada: Jakarta.

Ulke, Volkan. 2011. Econometric Analysis of Import and Inflation Relationship in Turkey between 1995 and 2010. Journal of Economic and Social Studies, Vol. 1, No. 2. 